\title{
Stimulation of Multiple Leader Formation in Some Genotypes of Acacia mangium and Acacia auriculiformis with 6-Benzylaminopurine (BAP)
}

\author{
Ahmed Mohamed Adam Eldoma1, Sures Kumar Muniandi², Nor Aini Ab Shukor 2,3* \\ ${ }^{1}$ College of Forestry and Range Sciences, Sudan University of Science and Technology, Khartoum, Sudan \\ ${ }^{2}$ Department of Forest Management, Faculty of Forestry, Universiti Putra Malaysia, Serdang, Malaysia \\ ${ }^{3}$ Institute of Tropical Forestry and Forest Product, Universiti Putra Malaysia, Serdang, Malaysia \\ Email: *anishukor@yahoo.com
}

Received 6 July 2015; accepted 18 September 2015; published 21 September 2015

Copyright @ 2015 by authors and Scientific Research Publishing Inc.

This work is licensed under the Creative Commons Attribution International License (CC BY).

http://creativecommons.org/licenses/by/4.0/

(c) (i) Open Access

\begin{abstract}
Acacia mangium Willd. and Acacia auriculiformis A. Cunn. ex. Benth. are two of the fast-growing tropical acacias which have received priority for genetic assessment and improvement. They were therefore proposed for timber production in a short rotation in Malaysia but were impeded by the multiple leaders (ML) formation which limited their value as sawn timber. This work attempts to investigate the causes of ML formation in four genotypes of $A$. mangium and $A$. auriculiformis as related to apical dominance, nutrition and plant growth hormones and their correlations. The effects of 6-benzylaminopurine and decapitation on ML formation of these genotypes were also investigated. 6-benzylaminopurine (BAP) as a foliar spray and also decapitation did not stimulate ML formation. However, they significantly increased the number of branches and reduced all other growth traits including height. However, basal diameter was not affected by decapitation. The effects of BAP increased consistently with increasing level of application. BAP at $1500 \mathrm{mg} \cdot \mathrm{L}^{-1} \mathrm{re}-$ sulted in mortality of $A$. mangium provenances while $A$. auriculiformis provenances survived and grew normally. Some of the BAP treated plants of both species developed juvenile pinnate leaves. Decapitation of the apical bud resulted in the activation of the lateral bud immediately below the point of decapitation.
\end{abstract}

\section{Keywords}

Cytokinin, Multiple Leader, Provenance, Genotypes, Apical Control, Stem Form

\footnotetext{
${ }^{*}$ Corresponding author.
}

How to cite this paper: Eldoma, A. M. A., Muniandi, S. K., \& Shukor, N. A. A. (2015). Stimulation of Multiple Leader Formation in Some Genotypes of Acacia mangium and Acacia auriculiformis with 6-Benzylaminopurine (BAP). Open Journal of Forestry, 5, 637-650. http://dx.doi.org/10.4236/ojf.2015.57056 


\section{Introduction}

The morphological and physiological basis of branching, crown structure and the development of tree trunk and form in relation to apical dominance and other concepts of shoot organization have been dealt with extensively in several reviews (Ishihara, 2013; Fumey, Lauri, Guedon, Godin, \& Costes, 2011; Lauri, Kelner, Trottier, \& Costes, 2010; Lauri, Bourdel, Trottier, \& Cochard, 2008; Lauri, 2007; Wilson, 2000; Ng, 1999; Cline, 1991; Hillman, 1984; Rubinstein \& Nagao, 1976; Philips, 1975; Brown, McAlpine, \& Kormanik, 1967). Apical control is the architecture of woody plants through regulation of branch angle, branch thickening, and bending movements (Wilson, 2000). There have been several studies conducted and focused on herbaceous plants to better understand the physiological and molecular processes involved in branching pattern of plants (Bennett \& Leyser, 2006; Dun, Fergusen, \& Beveridge, 2006; Leyser, 2003; Cline, 1997).

However, there exist some important practical and economic implications in agriculture and forestry that necessitate the understanding of the controlling mechanism of lateral bud out growth, tillering and multiple trunk formation by apical structures of the shoot. The long established practices of pruning and training of plants for ornamental purposes and increased food production involved the manipulation of lateral bud outgrowth in several types of plants (Fumey, Lauri, Guedon, Godin, \& Costes, 2011; Loreti \& Pisani, 1990). Most of this work has concentrated in the use of chemical induction of lateral branch shoots (feathers) using cytokinins in agricultural crops (Elfving, 1984, 1985; Harrison \& Kaufman, 1980; Sachs \& Thimann, 1964); less work has been reported on forest trees (Brar, 2012; Little, 1985; Kossuth, 1978; Cohen, 1978).

The exogenous application of osmoprotectants, growth promoters and antioxidant compounds to plants has been considered as a short-term solution to alleviate the adverse effects of stress and further enhance the vegetative growth of the plant when some physiological and biochemical changes occur (Radhika \& Thind, 2013; Raza, Athar, \&Ashraf, 2006). Exogenous application of cytokinins has been shown to activate lateral buds under apical control and apical dominance (Elfving, 1984; 1985; Boswell, Nauer, \& Storey, 1981; Croxdale, 1967) and has been found effective in stimulating metabolic activity and growth in buds of woody plant species (Nauer \& Boswell, 1981; Broome \& Zimmermann, 1976; Boswell \& Storey, 1974). The few examples on the use of chemical induction agents for tillering or multiple trunk formation in forestry include, for instance, Picea abies (Chen, Bollmark, \& Eliasson, 1996), Abies balsamea (Little, 1984, 1985), Macadamia teteraphylla (Boswell, Nauer, \& Storey, 1981), Pinus strobus (Cohen, 1978) and Pinus sylvesteris (Kossuth, 1978). However, 6-benzylaminopurine (BAP) was reported to be the most effective cytokinin. BAP is considered to be an appropriate cytokinins for exogenous plant application because of it stability compared to other natural cytokinins and can be readily taken up by the plant without degradation by cytokinin oxidase. BAP is also believed to be ideal cytokinin to overcome water stress related detrimental effects by accelerating leaf senescence and leaf growth and enhance the plant ability to recover and grow. It also tends to promote synthesis of protein and delay the aging process which is associated with maintenance of photosynthetic activity and increase in net photosynthetic rates by increasing the chlorophyll content (Radhika \& Thind, 2013; Chernyad'ev, 2005; Monakhova \& Chernyad'ev, 2004; Ron'zhina, 2003; Pospisilova, Synkova, \& Rulcova, 2000).

Both acacia species were found to form multiple leaders when grown on slashed and burnt sites. We therefore hypothesize that the apical control of these acacia species is somehow affected by multiple environmental factors including the nutrient status that according to the nutritive theory is influenced by hormonal regulation. This work was therefore undertaken to verify the role of 6-benzylaminopurine in inducing ML formation in these acacia species according to these hormonal correlations.

\section{Materials and Methods}

\subsection{Plant Materials}

Four genotypes, two provenances each of $A$. mangium and A. auriculiformis were used. The A. mangium provenances were from Oriomo Province WP PNG and Tully Mission Beach QLD while the A. auriculiformis were from SSG Fiji PNG and Elizabeth River NT. Their particulars were as described in Eldoma, Kumar, \& Shukor (2015). Sufficient seedlings were raised and kept under glass house environment and were given care, watering, and protection for three months before applying the treatments.

\subsection{Experimental Design and Treatments}

A $4 \times 5$ factorial experiment in a complete randomized arrangement of treatments viz. four genotypes, four 6- 
benzylaminopurine (BAP) concentration levels and decapitation was adopted. Each treatment had 8 replicates. One hundred and sixty potted plants of approximately the same size and vigor were selected and maintained in a glasshouse. The treatments applied included concentrations of $0,500,1000,1500 \mathrm{mg} \cdot \mathrm{L}^{-1}$ BAP in addition to decapitation.

\subsection{Chemical Preparations and Mode of Application}

6-benzylaminopurine (BAP) obtained from Sigma was first dissolved in 5\% dimethylsulfoxide (DMSO) and supplemented with polyoxyethylene sorbitan monolaurate (Tween $20,1.5 \% \mathrm{v} / \mathrm{v}$ ) as a surfactant-to ensure a good contact between the plant and the chemical-and then diluted with ethanol $95 \%$ according to the different concentrations and volumes required following the procedure of Boswell, Nauer, \& Storey (1981). Four different concentrations were thus prepared viz., $500 \mathrm{mg} \cdot \mathrm{L}^{-1}, 1000 \mathrm{mg} \cdot \mathrm{L}^{-1}$ and $1500 \mathrm{mg} \cdot \mathrm{L}^{-1}$. For the $0 \mathrm{mg} \cdot \mathrm{L}^{-1}$ concentration level the Tween-20 and ethanol were used to prepare the spray solution as well. Application was made once as single foliage spray. Solutions were applied to run-off with a hand pump sprayer to all above ground plant parts from the apex to the base. Each single seedling received $50 \mathrm{ml}$ of solution irrespective of the treatment. Plants were watered thoroughly one day prior to treatment and not watered again until at least 48 hours after treatment.

\subsection{Growth Parameters and Data Analysis}

Total plant height, basal stem diameter, number of branches, and clear bole length were measured before harvesting. Leaf area was determined using a leaf area meter and total above ground biomass was determined in the laboratory. Data were subjected to an analysis of variance (ANOVA). SAS System Software Release Version 6.12 was utilized and means values of all the treatments were compared and separated by Duncan's New Multiple Range Test.

\section{Results}

No multiple leaders were induced in the four genotypes by either 6-benzylaminopurine or decapitation. ANOVA results showed highly significant differences between genotypes as well as between the BAP treatment levels and decapitation for all growth characteristics investigated (Table 1). However, the two-way interaction of genotype $\mathrm{x}$ treatment was significant for dear bole length, total above ground biomass and basal diameter but not for height, number of branches and leaf area variables.

Observation revealed variations between genotypes in their tolerance to BAP application, reversion to the juvenile pinnate leaves, the mode of distribution of branches on the nodes and the restoration of leader dominance after decapitation. In this connection, the BAP $1500 \mathrm{mg} \cdot \mathrm{L}^{-1}$ level resulted in $100 \%$ mortality of $\mathrm{A}$. mangium provenances associated with complete leaf loss while $A$. auriculiformis provenances were able to survive and grow normally with only limited leaf loss and complete recovery was observed at about 4 weeks after BAP application. About $50 \%$ of the cytokinin-treated plants irrespective of species developed the juvenile pinnate small leaves on the branches and they persisted until the end of the experiment which lasted 4 months (Figure 1(a) and Figure 1(b)).

However, the reversion did not occur in the decapitated or the untreated controls. A marked change in the mode of branch insertion along the stem was also observed. The branches clustered in various numbers at some

Table 1. ANOVA summary on growth characteristics of $A$. mangium and A. auriculiformis genotypes (mean squares and associated level of significance).

\begin{tabular}{|c|c|c|c|c|c|c|c|}
\hline $\begin{array}{l}\text { Source of } \\
\text { variation }\end{array}$ & df & Height & $\begin{array}{c}\text { Basal } \\
\text { diameter }\end{array}$ & $\begin{array}{c}\text { Number of } \\
\text { branches }\end{array}$ & $\begin{array}{c}\text { Clear bole } \\
\text { length }\end{array}$ & Leaf area & $\begin{array}{l}\text { Total dry } \\
\text { weight }\end{array}$ \\
\hline Genotype & 3 & $0.94^{* * *}$ & $72.88^{* * *}$ & $702.00^{* * *}$ & $5370.53^{* * *}$ & $67,429,580.24^{* * *}$ & $37,499.67^{* * *}$ \\
\hline Treatments & 4 & $1.48^{* * *}$ & $40.07^{* * *}$ & $589.00^{* * *}$ & $1645.73^{* * *}$ & $135,285,878.98^{* * *}$ & $16,785.44^{* * *}$ \\
\hline $\mathrm{G} \times \mathrm{T}$ & 10 & $0.03^{\mathrm{ns}}$ & $9.57^{* *}$ & $9.99^{\text {ns }}$ & $204.60^{* * *}$ & $3,866,267.63^{\mathrm{ns}}$ & $964.32^{* * *}$ \\
\hline
\end{tabular}

${ }^{* * *}$ Significantly different at $P<0.001 ;{ }^{* *}$ significantly different at $P<0.01 ;{ }^{\text {ns }}$ non significant; $\mathrm{G} \times \mathrm{T}=$ Genotype $\times$ treatment interaction. 


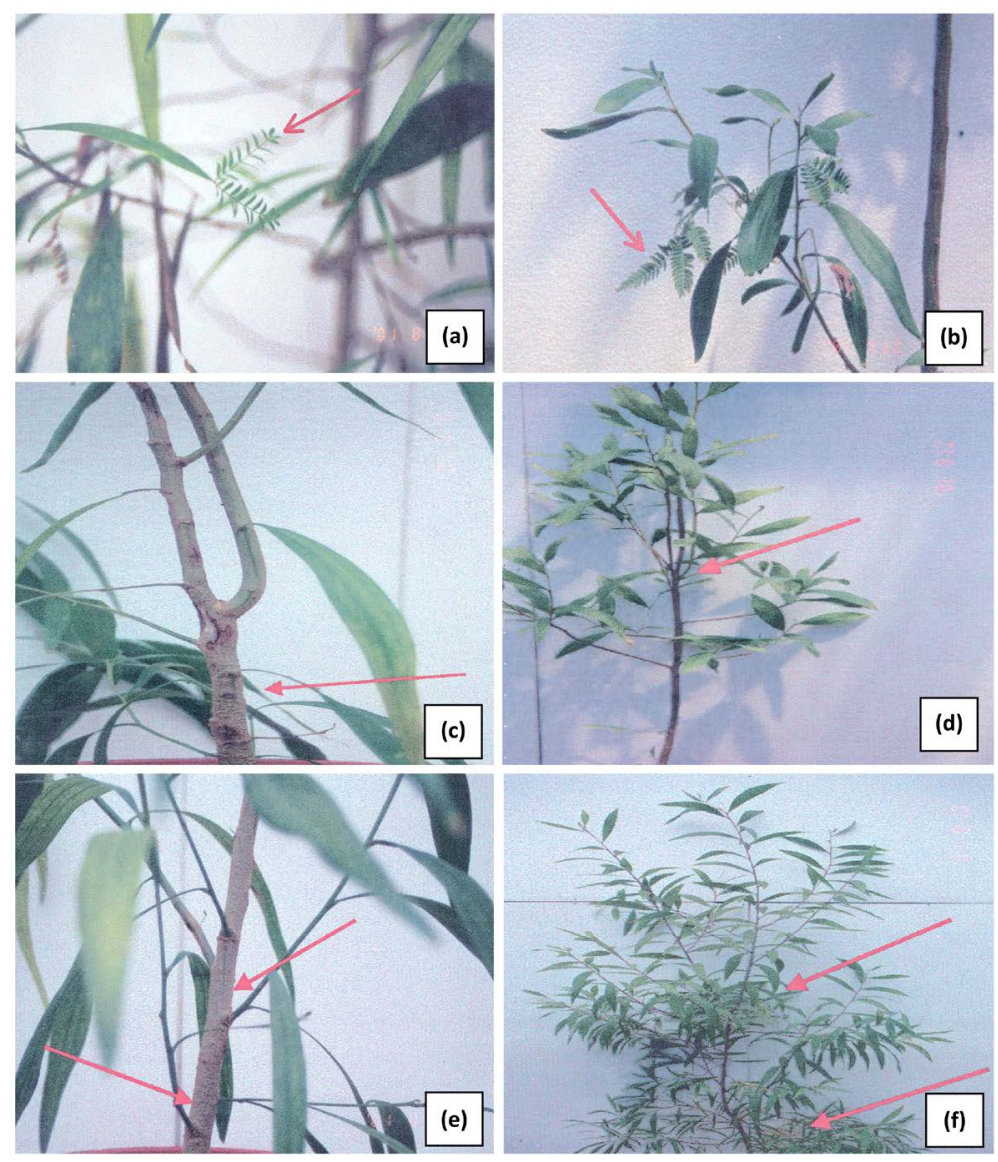

Figure 1. A. auriculiformis (a) and $A$. mangium (b) seedlings displaying the pinnate juvenile leaves as an after effect of 6-benzylaminopurine. A. mangium seedlings ((c) and (d)) showing branch clustering at one node with small angle as a result of the use of 6-benzylaminopurine. A. auriculiformis seedlings showing branching at the lower part (e) and clustering at two nodes as a result of the use of 6-benzylaminopurine (f).

nodes at irregular internodes lengths along the stem with mainly narrow angles (Figures 1(c)-(f)). Decapitation of the apical bud resulted in the activation of the lateral bud immediately below the point of decapitation. In all decapitated plants the second order lateral branch immediately assumed dominance over the rest of the lateral branches by substituting the original apical leader that had been decapitated (Figure 1(e) and Figure 1(f)).

\subsection{Height Growth}

The four BAP levels and decapitation showed significant differences between them in height growth. The mean height was $1.83 \mathrm{~m}$ and it ranged from $1.56 \mathrm{~m}$ (BAP $1500 \mathrm{mg} \cdot \mathrm{L}^{-1}$ ) to $2.20 \mathrm{~m}$ (Control). BAP application significantly reduced height growth. However, height decreased consistently with increasing level of BAP. Decapitation also caused significant reduction in height growth compared to the control (Table 2).

The four genotypes indicated significant differences between them as well. The mean height was $1.87 \mathrm{~m}$. It ranged from $1.66 \mathrm{~m}$ (A. auriculiformis SSG Fiji) to $2.03 \mathrm{~m}$ (A. mangium Oriomo-Province). A. mangium provenances showed significant differences between them ranging from $1.90 \mathrm{~m}$ (Tully Mission Beach) to $2.03 \mathrm{~m}$ (Oriomo Province). On the other hand A. auriculiformis also showed significant differences between its provenances ranging from $1.66 \mathrm{~m}$ (SSO Fiji) to $1.89 \mathrm{~m}$ (Elizabeth River) (Table 3).

All BAP and decapitation treatment combinations $\times$ genotype reduced height growth relative to the control (Table 4). The least reduction in all combinations was caused by decapitation. Maximum height reduction was caused by BAP $1000 \mathrm{mg} \cdot \mathrm{L}^{-1}$ in the case of A. mangium provenances while for A. auriculiformis it was caused by BAP $1500 \mathrm{mg} \cdot \mathrm{L}^{-1}$. The treatment combinations showed significant differences between them in height growth, 
Table 2. Effect of different levels of BAP and decapitation on mean growth characteristics of A. mangium and A. auriculiformis genotypes.

\begin{tabular}{|c|c|c|c|c|c|c|}
\hline Treatment & Height (m) & $\begin{array}{l}\text { Basal diameter } \\
(\mathrm{mm})\end{array}$ & Branch number & Clear bole $(\mathrm{cm})$ & Leaf area $\left(\mathrm{cm}^{2}\right)$ & $\begin{array}{r}\text { Total dry } \\
\text { weight }(\mathrm{g})\end{array}$ \\
\hline Control & $2.2^{\mathrm{a}}$ & $15.21^{\mathrm{a}}$ & $14^{\mathrm{e}}$ & $29.73^{a}$ & $11,456.20^{\mathrm{a}}$ & $197.68^{\mathrm{a}}$ \\
\hline Decapitation & $1.95^{\mathrm{b}}$ & $14.58^{\mathrm{a}}$ & $16^{\mathrm{d}}$ & $20.63^{b}$ & $10,277.30^{\mathrm{b}}$ & $191.94^{\mathrm{b}}$ \\
\hline $500 \mathrm{mg} \cdot \mathrm{L}^{-1}$ & $1.77^{b}$ & $13.36^{\mathrm{b}}$ & $21^{\mathrm{c}}$ & $16.71^{\mathrm{c}}$ & $8457.70^{\mathrm{c}}$ & $162.94^{\mathrm{c}}$ \\
\hline $1000 \mathrm{mg} \cdot \mathrm{L}^{-1}$ & $1.68^{\mathrm{d}}$ & $13.24^{\mathrm{b}}$ & $24^{\mathrm{b}}$ & $10.66^{\mathrm{d}}$ & $6476.00^{\mathrm{d}}$ & $149.88^{\mathrm{d}}$ \\
\hline $1500 \mathrm{mg} \cdot \mathrm{L}^{-1}$ & $1.56^{\mathrm{e}}$ & $12.52^{\mathrm{b}}$ & $28^{\mathrm{a}}$ & $6.56^{\mathrm{e}}$ & $5991.70^{\mathrm{d}}$ & $120.04^{\mathrm{e}}$ \\
\hline
\end{tabular}

Mean values followed by the same letter in a column are not significantly different using Duncan's new multiple range test at $P<0.05$.

Table 3. Effect of the genotype on mean growth characteristics.

\begin{tabular}{|c|c|c|c|c|c|c|}
\hline Genotype & $\begin{array}{l}\text { Height } \\
\text { (m) }\end{array}$ & $\begin{array}{l}\text { Basal diameter } \\
(\mathrm{mm})\end{array}$ & $\begin{array}{l}\text { Branch } \\
\text { number }\end{array}$ & $\begin{array}{l}\text { Clear bole } \\
(\mathrm{cm})\end{array}$ & $\begin{array}{l}\text { Leaf area } \\
\quad\left(\mathrm{cm}^{2}\right)\end{array}$ & $\begin{array}{r}\text { Total dry } \\
\text { weight }(\mathrm{g})\end{array}$ \\
\hline A. mangium Oriomo Province (AM ORP) & $2.03^{\mathrm{a}}$ & $13.60^{\mathrm{b}}$ & $14^{\mathrm{d}}$ & $37.56^{\mathrm{a}}$ & $10,953.6^{\mathrm{a}}$ & $217.73^{\mathrm{a}}$ \\
\hline A. mangium Tully Mission Beach (AM TMB) & $1.90^{\mathrm{b}}$ & $13.10^{\mathrm{cb}}$ & $18^{\mathrm{c}}$ & $15.28^{\mathrm{b}}$ & $8541.00^{\mathrm{b}}$ & $172.36^{\mathrm{b}}$ \\
\hline A. auriculiformis Elizabeth River (AU ER) & $1.89^{\mathrm{b}}$ & $15.77^{\mathrm{a}}$ & $25^{\mathrm{a}}$ & $11.41^{\mathrm{c}}$ & $8399.30^{\mathrm{b}}$ & $156.04^{\mathrm{c}}$ \\
\hline A. auriculiformis SSO Fiji (AU SSOF) & $1.66^{\mathrm{c}}$ & $12.71^{\mathrm{c}}$ & $21^{\mathrm{b}}$ & $11.12^{\mathrm{c}}$ & $7735.50^{\mathrm{c}}$ & $141.85^{\mathrm{d}}$ \\
\hline
\end{tabular}

Mean values followed by the same letter in a column are not significantly different using Duncan's new multiple range test at $P<0.05$.

Table 4. Effect of different levels of BAP applications and decapitation on growth characteristics of A. mangium and A. auriculiformis genotypes (mean \pm standard deviation).

\begin{tabular}{|c|c|c|c|c|c|c|c|}
\hline Genotype & Treatment & $\begin{array}{l}\text { Height } \\
\text { (m) }\end{array}$ & $\begin{array}{l}\text { Basal diameter } \\
(\mathrm{mm})\end{array}$ & $\begin{array}{c}\text { Number } \\
\text { of branches }\end{array}$ & $\begin{array}{l}\text { Clear bole } \\
\text { length }(\mathrm{cm})\end{array}$ & Leaf area $\left(\mathrm{cm}^{2}\right)$ & $\begin{array}{c}\text { Total dry } \\
\text { weight }(\mathrm{g})\end{array}$ \\
\hline \multirow{4}{*}{$\begin{array}{l}\text { A. mangium } \\
\text { Oriomo } \\
\text { Province }\end{array}$} & BAP $500 \mathrm{mg} \cdot \mathrm{L}^{-1}$ & $1.84 \pm 0.01$ & $12.56 \pm 1.19^{\mathrm{def}}$ & $17.00 \pm 3$ & $35.25 \pm 6.16^{\mathrm{c}}$ & $10,514.45 \pm 1967.46$ & $204.32 \pm 6.94^{\mathrm{c}}$ \\
\hline & BAP $1000 \mathrm{mg} \cdot \mathrm{L}^{-1}$ & $1.77 \pm 0.09$ & $11.11 \pm 1.96^{\mathrm{fg}}$ & $19.00 \pm 2$ & $17.87 \pm 1.8 \mathrm{I}^{\mathrm{ef}}$ & $7105.06 \pm 1550.07$ & $186.00 \pm 13.64^{\mathrm{de}}$ \\
\hline & Decapitation & $2.08 \pm 0.04$ & $14.76 \pm 1.41^{\mathrm{abc}}$ & $12.00 \pm 2$ & $43.63 \pm 4.7 \mathrm{I}^{\mathrm{b}}$ & $12,198.40 \pm 1754.68$ & $226.20 \pm 11.39^{b}$ \\
\hline & Control & $2.45 \pm 0.26$ & $15.96 \pm 1.45^{\mathrm{ab}}$ & $10.00 \pm 2$ & $53.50 \pm 7.82^{\mathrm{a}}$ & $\mathrm{I} 3,996.62 \pm 1666.78$ & $254.39 \pm 9.48^{\mathrm{a}}$ \\
\hline \multirow{4}{*}{$\begin{array}{c}\text { A. mangium } \\
\text { Tully Mission } \\
\text { Beach }\end{array}$} & BAP $500 \mathrm{mg} \cdot \mathrm{L}^{-1}$ & $1.80 \pm 0.12$ & $12.00 \pm 1.26^{\mathrm{def}}$ & $21.00 \pm 3$ & $11.49 \pm 1.79^{\text {ghi }}$ & $8313.33 \pm 1607.66$ & IS $2.99 \pm 5.71^{\mathrm{f}}$ \\
\hline & BAP $1000 \mathrm{mg} \cdot \mathrm{L}^{-1}$ & $1.65 \pm 0.21$ & $10.40 \pm 1.49^{\mathrm{g}}$ & $23.00 \pm 2$ & $13.00 \pm 1.36^{\mathrm{ghi}}$ & $6466.04 \pm 1463.43$ & $142.57 \pm 10.39^{g}$ \\
\hline & Decapitation & $1.95 \pm 0.11$ & $14.0 \pm 0.84^{\mathrm{bcd}}$ & $14.00 \pm 1$ & $13.75 \pm 2.05^{\mathrm{fg}}$ & $9266.48 \pm 854.04$ & $188.86 \pm 8.20^{\mathrm{d}}$ \\
\hline & Control & $2.19 \pm 0.19$ & $\mathrm{I} 5.37 \pm \mathrm{I} .14^{\mathrm{ab}}$ & $13.00 \pm 2$ & $26.751 \pm 1.36^{\mathrm{d}}$ & $10,118.20 \pm 943.11$ & $204.02 \pm 8.22^{c}$ \\
\hline \multirow{5}{*}{$\begin{array}{l}\text { A. auriculiformis } \\
\text { Elizabeth River }\end{array}$} & BAP $500 \mathrm{mg} \cdot \mathrm{L}^{-1}$ & $1.81 \pm 0.21$ & $15.87 \pm 1.73^{\mathrm{ab}}$ & $24.00 \pm 4$ & $13.00 \pm 4.82^{\mathrm{ghi}}$ & $8305.07 \pm 1635.22$ & $155.49 \pm 9.71^{\mathrm{f}}$ \\
\hline & BAP $1000 \mathrm{mg} \cdot \mathrm{L}^{-1}$ & $1.74 \pm 0.27$ & $15.36 \pm 2.17^{\mathrm{ab}}$ & $27.00 \pm 3$ & $8.37 \pm 1.69^{\mathrm{ghi}}$ & $6052.70 \pm 1582.62$ & $138.64 \pm 5.56^{\mathrm{g}}$ \\
\hline & BAP $1500 \mathrm{mg} \cdot \mathrm{L}^{-1}$ & $1.64 \pm 0.14$ & $14.81 \pm 1.59^{\mathrm{abc}}$ & $30.00 \pm 4$ & $6.63 \pm 1.69^{\mathrm{i}}$ & $6136.38 \pm 1523.55$ & $118.85 \pm I 5.33^{\mathrm{h}}$ \\
\hline & Decapitation & $2.01 \pm 0.10$ & $16.67 \pm 1.58^{\mathrm{a}}$ & $21.00 \pm 5$ & $12.65 \pm 2.00^{\mathrm{gh}}$ & $10,030.36 \pm 995.35$ & $189.98 \pm 10.88^{\mathrm{d}}$ \\
\hline & Control & $2.26 \pm 0.22$ & $16.14 \pm 1.25^{\mathrm{a}}$ & $20.00 \pm 2$ & $20.28 \pm 9.70^{\mathrm{e}}$ & $11,471.95 \pm 2225.25$ & $177.22 \pm 16.86^{\mathrm{e}}$ \\
\hline \multirow{5}{*}{$\begin{array}{l}\text { A. auriculiformis } \\
\text { SSO Fiji }\end{array}$} & BAP $500 \mathrm{mg} \cdot \mathrm{L}^{-1}$ & $1.63 \pm 0.14$ & $12.52 \pm 1.98^{\mathrm{def}}$ & $22.00 \pm 3$ & $11.00 \pm 2.92^{\text {ghi }}$ & $6697.81 \pm 967.11$ & $138.95 \pm 19.29^{\mathrm{g}}$ \\
\hline & BAP $1000 \mathrm{mg} \cdot \mathrm{L}^{-1}$ & $1.56 \pm 0.08$ & $13.23 \pm 0.86^{\text {cde }}$ & $24.00 \pm 4$ & $7.25 \pm 2.12^{\mathrm{hi}}$ & $6280.23 \pm 1096.50$ & $132.32 \pm 10.25^{\mathrm{g}}$ \\
\hline & BAP $1500 \mathrm{mg} \cdot \mathrm{L}^{-1}$ & $1.48 \pm 0.09$ & $11.68 \pm 1.81^{\mathrm{efg}}$ & $26.00 \pm 3$ & $6.50 \pm 1.60^{\mathrm{i}}$ & $5847.09 \pm 1442.73$ & $121.24 \pm 16.49^{\mathrm{h}}$ \\
\hline & Decapitation & $1.75 \pm 0.14$ & $12.76 \pm 2.48^{\mathrm{def}}$ & $19.00 \pm 2$ & $12.50 \pm 1.77^{\mathrm{gh}}$ & $9614.15 \pm 1087.53$ & $162.69 \pm 11.75^{\mathrm{f}}$ \\
\hline & Control & $1.91 \pm 0.11$ & $13.40 \pm 2.94^{\text {cde }}$ & $14.00 \pm 3$ & $18.38 \pm 2.20^{\mathrm{ef}}$ & $10,238.12 \pm 1522.42$ & $154.10 \pm 7.86^{\mathrm{f}}$ \\
\hline
\end{tabular}

Means followed by the same letter in a column are not significantly different $(P<0.05)$ using Duncan's multiple range test. Note: The interaction for genotype $\times$ treatment was not significant for total height, number of branches and leaf area parameter. 
no which generally ranged from $1.48 \mathrm{~m}$ (A. auriculiformis SSG Fiji/BAP $\left.1500 \mathrm{mg} \cdot \mathrm{L}^{-1}\right)$ to $2.45 \mathrm{~m}($ A. mangium Oriomo Province/Control). A. mangium provenances indicated significant differences between their respective treatment combinations ranging from $1.65 \mathrm{~m}$ (Tully Mission Beach/BAP $1000 \mathrm{mg} \cdot \mathrm{L}^{-1}$ ) to $2.45 \mathrm{~m}$ (Oriomo Province/Control). On the other hand, A. auriculiformis also showed significant differences between its provenances ranging from $1.56 \mathrm{~m}$ (SSO Fiji/BAP $1500 \mathrm{mg} \cdot \mathrm{L}^{-1}$ ) to $2.26 \mathrm{~m}$ (Elizabeth River/Control). Height growth response of the different genotypes to BAP levels and decapitation is compared (Figure 2(a)).

\subsection{Basal Diameter Growth}

The different BAP levels and decapitation showed significant differences between them in basal diameter. The mean was $13.78 \mathrm{~mm}$ and it ranged from $12.52 \mathrm{~mm}$ (BAP $500 \mathrm{mg} \cdot \mathrm{L}^{-1}$ ) to $15.21 \mathrm{~mm}$ (Control). Basal diameter was significantly decreased by BAP levels but not by decapitation compared to the control. However, there were no significant differences between the three levels of the BAP (Table 2). The genotypes showed significant differences between them in basal diameter as well. The mean was $13.80 \mathrm{~mm}$ ranging from $12.71 \mathrm{~mm}(\mathrm{~A}$. auriculiformis SSO Fiji) to $15.77 \mathrm{~mm}$ (A. auriculiformis Elizabeth River). A. mangium provenances showed significant differences between them ranging from $13.10 \mathrm{~mm}$ (Tully Mission Beach) to $13.60 \mathrm{~mm}$ (Oriomo Province). On the other hand $A$. auriculiformis showed significant differences between its provenances and it ranged as mentioned above (Table 3 ).

The effect of the genotype x BAP and decapitation treatments combinations in the various growth characteristics is given in Table 4 . In this connection, the BAP and decapitation treatment combination $\times$ genotypes generally reduced basal diameter growth relative to the control except for decapitation combination involving $A$. auriculiformis Elizabeth River (Table 4). Decapitation resulted in the smallest reduction while in most combinations maximum basal diameter decrease was caused by BAP $1000 \mathrm{mg} \cdot \mathrm{L}^{-1}$ in the case of $A$. mangium provenances and BAP $1500 \mathrm{mg} \cdot \mathrm{L}^{-1}$ in the case of $A$. auriculiformis. The various treatments $\times$ genotype combinations showed significant differences between them in basal diameter growth, which generally ranged from $10.40 \mathrm{~mm}$ (A. mangium Tully Mission Beach/BAP $1000 \mathrm{mg} \cdot \mathrm{L}^{-1}$ ) to $16.67 \mathrm{~mm}$ (A. auriculiformis Elizabeth River/Decapitation). A. mangium provenances indicated significant differences between their respective treatment combinations ranging from $10.40 \mathrm{~mm}$ (Tully Mission Beach/BAP $1000 \mathrm{mg} / \mathrm{L}$ ) to $15.96 \mathrm{~mm}$ (Oriomo Province/Control). On the other hand, A. auriculiformis also showed significant differences between its provenances ranging from $11.68 \mathrm{~mm}$ (SSO Fiji/BAP $1500 \mathrm{mg} \cdot \mathrm{L}^{-1}$ ) to $16.67 \mathrm{~mm}$ (Elizabeth River/Decapitation). Basal diameter growth response of the different genotypes to BAP levels and decapitation is compared as illustrated in Figure 2(b).

\subsection{Clear Bole Length}

The various BAP treatment levels and decapitation showed significant differences between them in clear bole length. The mean clear bole length was $16.86 \mathrm{~cm}$ and it ranged from $6.56 \mathrm{~cm}$ (BAP $1500 \mathrm{mg} \cdot \mathrm{L}^{-1}$ ) to $29.73 \mathrm{~cm}$ (Control). The clear bole length decreased significantly with increasing level of BAP. Decapitation also significantly decreased the clear bole length relative' to the control but however less pronounced than the BAP concentration levels (Table 2).

The genotypes showed significant differences between them in clear bole length as well. The mean was 18.84 $\mathrm{cm}$ and it ranged from 11.12 (A. auriculiformis SSO Fiji) to $37.56 \mathrm{~cm}$ (A. mangium Oriomo Province). A. mangium provenances showed significantly longer clear boles compared to A. auriculiformis. However, they showed significant differences between them ranging from 15.28 (Tully Mission Beach) to $37.56 \mathrm{~cm}$ (Oriomo Province). On the other hand $A$. auriculiformis showed no significant differences between its provenances and the mean clear bole ranged from $11.12 \mathrm{~cm}$ (SSO Fiji) to $11.41 \mathrm{~cm}$ (Elizabeth River).

The effect of the genotype $\mathrm{x}$ BAP and decapitation treatment combinations in the various growth characteristics is given in Table 4. The different levels of BAP and decapitation treatment combinations $\mathrm{x}$ genotypes, generally decreased the clear bole length compared to the control. Decapitation resulted in the smallest decrease in clear bole length while the greatest reduction was induced by BAP $1000 \mathrm{mgL}^{-1}$ in the case of A. mangium provenances and BAP $1500 \mathrm{mg} \cdot \mathrm{L}^{-1}$ in the case of $A$. auriculiformis. However, in all BAP treatment combinations with the different genotypes the clear bole length decreased with increasing level of BAP application.

The treatments $\times$ genotype combinations showed significant differences between them in clear bole length, which generally ranged from $6.50 \mathrm{~cm}$ (A. auriculiformis SSG Fiji/BAP $\left.1500 \mathrm{mg} \cdot \mathrm{L}^{-1}\right)$ to $53.50 \mathrm{~cm}($ A. mangium Oriomo Province/Control). A. mangium provenances indicated significant differences between their respective 


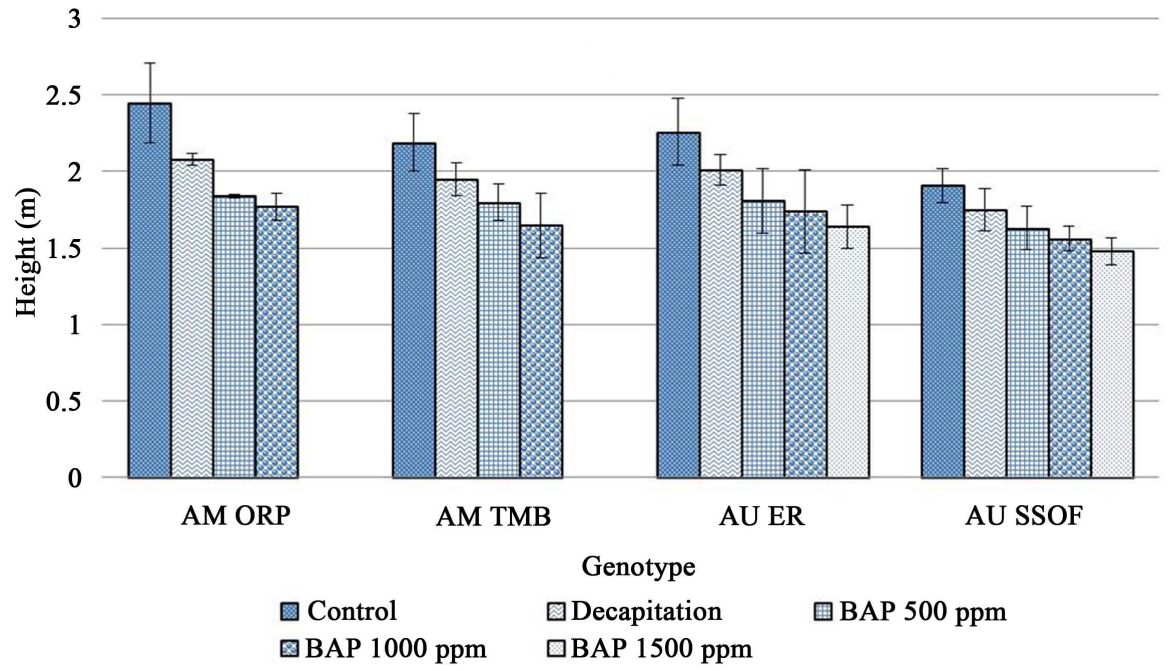

(a)
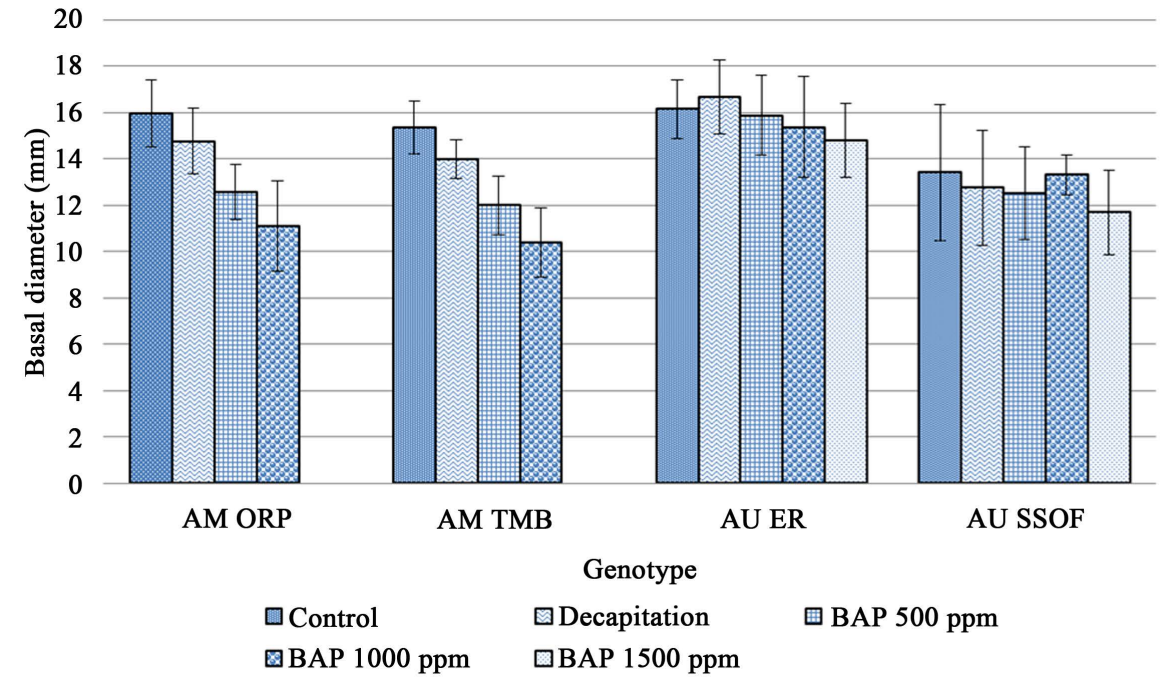

(b)

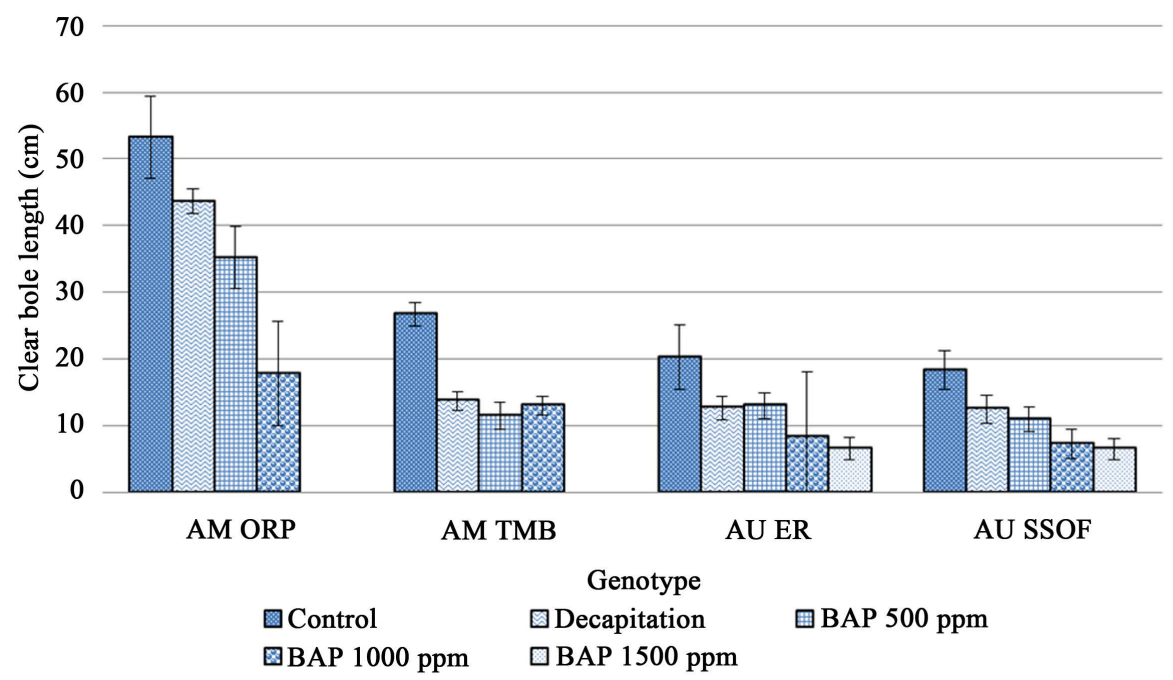

(c) 


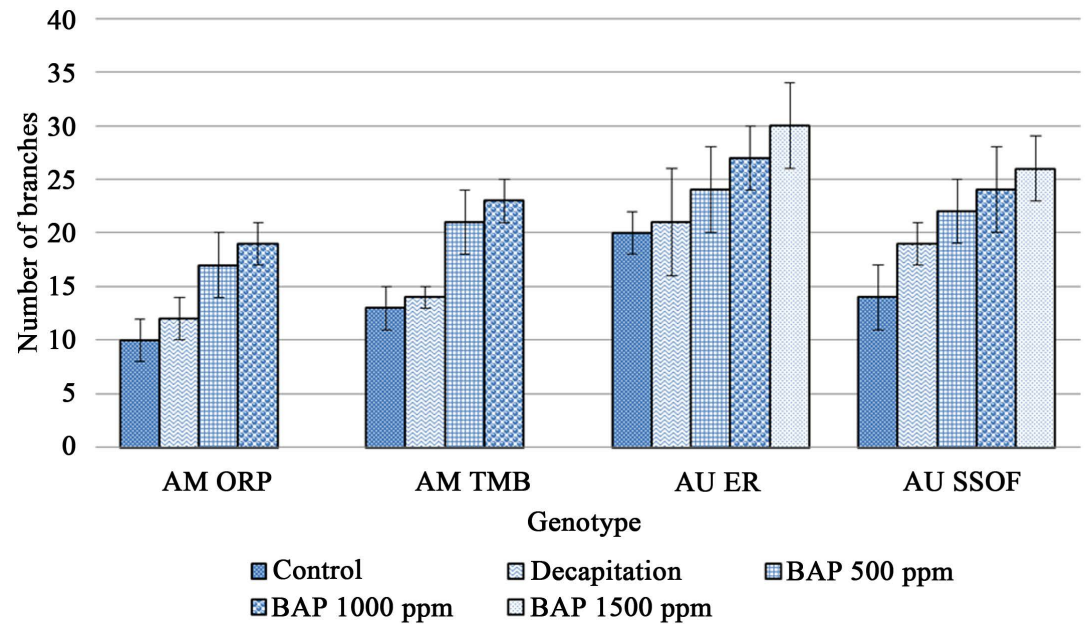

(d)

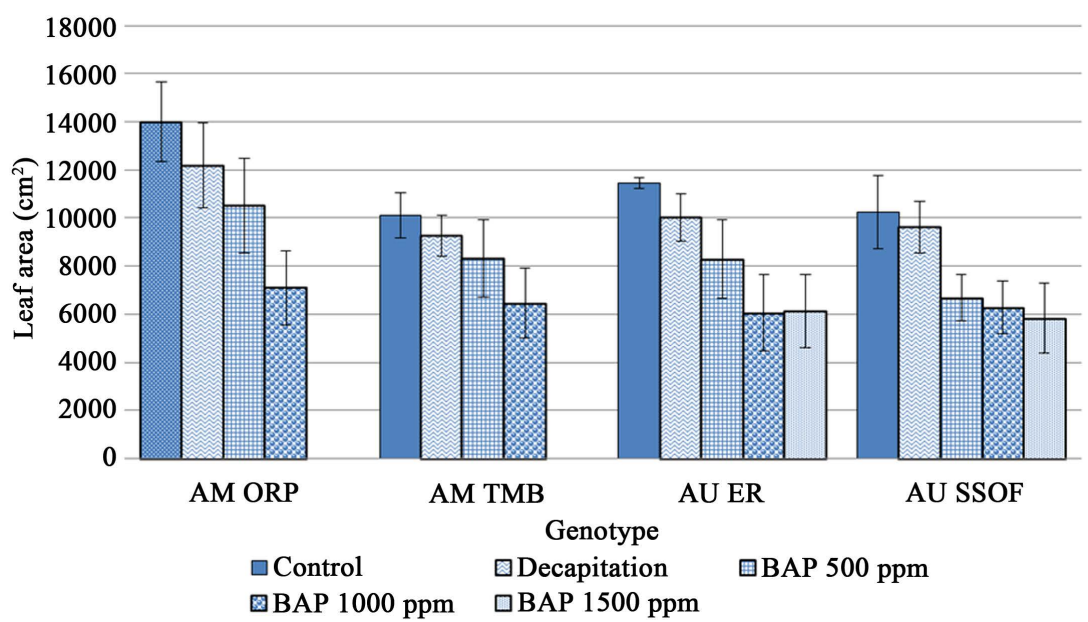

(e)

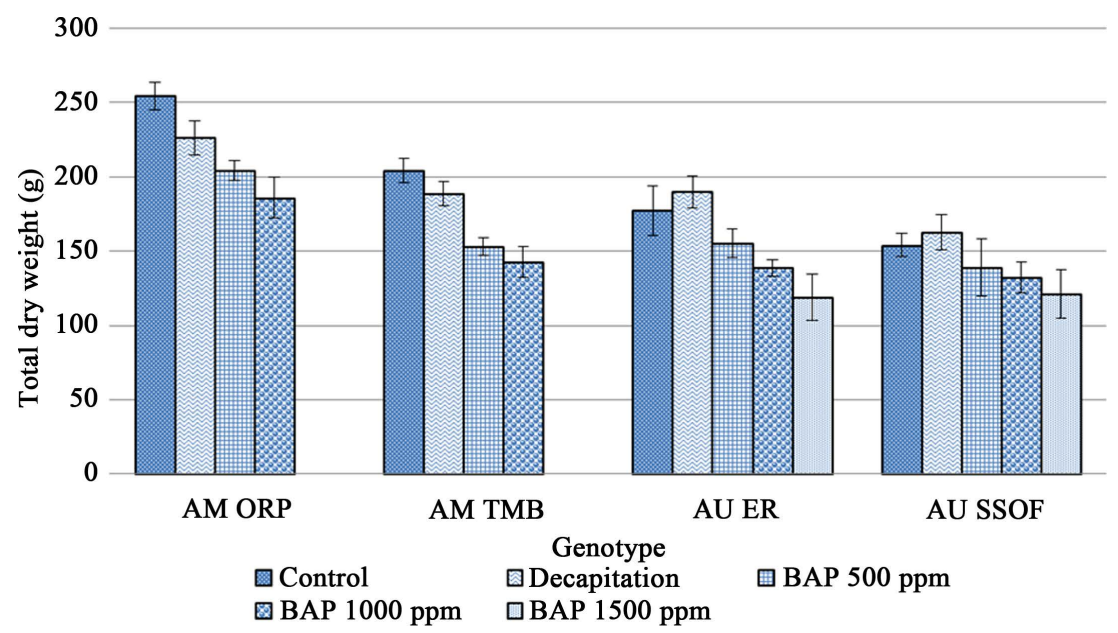

(f)

Figure 2. Growth responses of $A$. mangium and A. auriculiformis genotypes to varied bap levels and decapitation treatments: (a) height, (b) diameter, (c) clear bole length, (d) number of branches, (e) leaf area and (f) total dry weight. Note: Abbreviations of the genotypes are the same as in Table 3. Vertical bars indicate standard error of the mean. 
treatment combinations in clear bole length ranging from $9.13 \mathrm{~cm}$ (Tully Mission Beach/BAP $500 \mathrm{mg} \cdot \mathrm{L}^{-1}$ ) to $53.0 \mathrm{~cm}$ (Oriomo Province/Control). On the other hand, A. auriculiformis also showed significant differences between its provenances ranging from $6.50 \mathrm{~cm}\left(\mathrm{SSO}\right.$ Fiji/BAP $1500 \mathrm{mg} \cdot \mathrm{L}^{-1}$ ) to $20.28 \mathrm{~cm}$ (Elizabeth River/Control). Clear bole response of the different genotypes to different levels of BAP and decapitation is compared as illustrated in Figure 2(c).

\subsection{Number of Branches}

The various BAP levels and decapitation showed significant differences between them in the number of branches characteristic. The mean was 21 branches and it ranged from 14 (Control) to 28 (BAP $1500 \mathrm{mg} \cdot \mathrm{L}^{-1}$ ). The number of branches increased significantly with increasing level of BAP. Decapitation also significantly increased the number of branches relative to the control (Table 2).

The four genotypes showed significant differences between them in the number of branches trait. The mean was 20 and it ranged from 14 (A. mangium Oriomo Province) to 25 (A. auriculiformis Elizabeth River). A. auriculiformis provenances showed significantly increased number of branches compared to A. mangium. However, A. mangium provenances showed significant differences between them ranging from 14 (Oriomo Province) to 18 (Tully Mission Beach). On the other hand A. auriculiformis also showed significant differences between its provenances and the mean number of branches ranged from 21 (SSO Fiji) to 25 (Elizabeth River).

The effect of the genotype $\times$ BAP and decapitation treatments combinations in the various growth characteristics is given in Table 4. The different levels of BAP and decapitation treatment combinations $\mathrm{x}$ genotypes, generally increased the number of branches relative to the control. Decapitation resulted in the fewest increase in the number of branches while the biggest number was induced by BAP $1000 \mathrm{mg} \cdot \mathrm{L}^{-1}$ in the case of A. mangium provenances and BAP $1500 \mathrm{mg} \cdot \mathrm{L}^{-1}$ in the case of A. auriculiformis. However, in all BAP levels combinations with the different genotypes the number of branches increased with increasing level of application.

The treatments $\times$ genotype combinations showed significant differences between them in the number of branches characteristic, which generally ranged from 10 (A. mangium Oriomo Province/Control) to 30 (A. auriculiformis Elizabeth River/BAP $\left.1500 \mathrm{mg} \cdot \mathrm{L}^{-1}\right)$. A. mangium provenances indicated significant differences between them in their respective treatment combinations ranging from 10 (Oriomo Province/ControJ) to 23 (Tully Mission Beach/BAP $1000 \mathrm{mg} \cdot \mathrm{L}^{-1}$ ). On the other hand, A. auriculiformis also showed significant differences between its provenances ranging from 14 (SSO Fiji /ControJ) to 30 (Elizabeth River/BAP $1500 \mathrm{mg} \cdot \mathrm{L}^{-1}$ ). The number of branches response of the different genotypes to different BAP levels and decapitation is compared as illustrated in Figure 2(d).

\subsection{Leaf Area}

The different BAP treatment levels and decapitation showed significant differences between them in leaf area characteristic. The mean was $8531.80 \mathrm{~cm}^{2}$ and it ranged from $5991.70 \mathrm{~cm}^{2}\left(\mathrm{BAP} 1500 \mathrm{mg} \cdot \mathrm{L}^{-1}\right.$ ) to $11,456.20 \mathrm{~cm}^{2}$ (Control). Leaf area decreased significantly with increasing level of BAP. However, the difference between the BAP $1000 \mathrm{mg} \cdot \mathrm{L}^{-1}$ and $1500 \mathrm{mg} \cdot \mathrm{L}^{-1}$ was not significant. Decapitation also significantly decreased the leaf area relative to the control but less pronounced than the BAP concentration levels (Table 2).

The four genotypes showed significant differences between them in leaf area. The mean was $8907.35 \mathrm{~cm}^{2}$ and it ranged from $7735.50 \mathrm{~cm}^{2}$ (A. auriculiformis SSO Fiji) to $10,953.60 \mathrm{~cm}^{2}$ (A. mangium Oriomo Province). However, A. mangium provenances showed significant differences between them ranging from $8541.00 \mathrm{~cm}^{2}$ (Tully Mission Beach) to $10953.60 \mathrm{~cm}^{2}$ (Oriomo Province). On the other hand A. auriculiformis also showed significant differences between its provenances and the mean leaf area ranged from 7735.50 (SSG Fiji) to $8399.30 \mathrm{~cm}^{2}$ (Elizabeth River) (Table 3).

The effect of the genotype $\mathrm{x}$ BAP and decapitation treatments combinations on the various growth characteristics is given in Table 4. The different levels of BAP and decapitation treatment combinations $\times$ genotypes, generally decreased the leaf area characteristic compared to the control. Decapitation resulted in the least reduction while the biggest reduction was induced by BAP $1000 \mathrm{mg} \cdot \mathrm{L}^{-1}$ for $A$. mangium provenances and BAP 1500 $\mathrm{mg} \cdot \mathrm{L}^{-1}$ for A. auriculiformis. However, in all BAP treatment combinations with the different genotypes leaf area decreased with increasing level of BAP.

The treatments $\times$ genotype combinations showed significant differences between them in leaf area, which generally ranged from $5847.09 \mathrm{~cm}^{2}$ (A. auriculiformis SSO Fiji/BAP $1500 \mathrm{mg} / \mathrm{L}$ ) to $13,996.62 \mathrm{~cm}^{2}$ (A. mangium 
Oriomo Province/Contro). A. mangium provenances indicated significant differences between their respective treatment combinations in leaf area ranging from $6466.04 \mathrm{~cm}^{2}$ (Tully Mission Beach/BAP $1000 \mathrm{mg} \cdot \mathrm{L}^{-1}$ ) to $13,996.62 \mathrm{~cm}^{2}$ (Oriomo Province/Control). On the other hand, A. auriculiformis also showed significant differences between its provenances ranging from $5847.09 \mathrm{~cm}^{2}$ (SSO Fiji/BAP $\left.1500 \mathrm{mg} \cdot \mathrm{L}^{-1}\right)$ to $11471.95 \mathrm{~cm}^{2}(\mathrm{Eliza}-$ beth River/Control). Leaf area response of the different genotypes to different BAP levels and decapitation is compared as illustrated in Figure 2(e).

\subsection{Total Dry Weight}

The different BAP treatment levels and decapitation showed significant differences between them in total dry weight variable. The mean was $164.50 \mathrm{~g}$ and it ranged from $120.04 \mathrm{~g}$ (BAP $1500 \mathrm{mg} \cdot \mathrm{L}^{-1}$ ) to $197.68 \mathrm{~g}$ (Control). Total dry weight decreased significantly with increasing levels of BAP. Decapitation also significantly decreased it relative to the control but less pronounced than the BAP concentration levels (Table 2).

The four genotypes showed significant differences between them in total dry weight. The mean was $171.91 \mathrm{~g}$ and it ranged from $141.85 \mathrm{~g}$ (A. auriculiformis SSO Fiji) to $217.73 \mathrm{~g}$ (A. mangium Oriomo Province). However, A. mangium provenances showed significant differences between them ranging from $172.36 \mathrm{~g}$ (Tully Mission Beach) to $217.73 \mathrm{~g}$ (Oriomo Province). On the other hand A. auriculiformis also showed significant differences between its provenances and the mean ranged from $141.85 \mathrm{~g}$ (SSO Fiji) to $156.04 \mathrm{~g}$ (Elizabeth River).

The effect of the genotype $\mathrm{x}$ BAP levels and decapitation treatment combinations on the various growth characteristics is given in Table 4. The different levels of BAP and decapitation treatment combinations $\mathrm{x}$ genotypes, generally decreased total dry weight compared to the control. Decapitation resulted in the minimum reduction while maximum reduction in total dry weight was induced by BAP $1000 \mathrm{mg} \cdot \mathrm{L}^{-1}$ for A. mangium provenances and BAP $1500 \mathrm{mg} \cdot \mathrm{L}^{-1}$ for $A$. auriculiformis. Total dry weight decreased with increasing levels of BAP for all treatment $\times$ genotype combinations.

The treatment $\times$ genotype combinations showed significant differences between them in total dry weight, which generally ranged from $118.45 \mathrm{~g}$ (A. auriculiformis Elizabeth River/BAP $\left.1500 \mathrm{mg} \cdot \mathrm{L}^{-1}\right)$ to $254.39 \mathrm{~g}(A$. mangium Oriomo Province/Control). A. mangium provenances indicated significant differences between their respective treatment combinations in total dry weight ranging from $142.57 \mathrm{~g}$ (Tully Mission Beach/BAP 1000 $\mathrm{mg} \cdot \mathrm{L}^{-1}$ ) to $254.39 \mathrm{~g}$ (Oriomo Province/Control). On the other hand, A. auriculiformis also showed significant differences between its provenances ranging from 118.85 (Elizabeth River/BAP $1500 \mathrm{mg} \cdot \mathrm{L}^{-1}$ ) to $189.98 \mathrm{~g}$ (Elizabeth River/Decapitation.). Total dry weight response of the different genotypes to the different levels of BAP and decapitation is compared as illustrated in Figure 2(f).

\section{Discussion}

In this study, 6-benzylaminopurine (BAP) did not induce multiple leader formation in the acacia genotypes studied. However, the results indicated that 6-benzylaminopurine (BAP) and decapitation were effective in inducing many physiological growth responses in the genotypes. These include the increased number of branches, their clustering at some nodes along the stem and the acute angles at which they grew (Figure 2(b)), and it also confirms its role in the release of lateral bud from apical control. In this connection Henny \& Fooshee (1985) reported a significantly increased number of basal shoot in (Tasson) Spathiphyllum following treatment with BAP as a soil drench compared to the untreated or plants treated with BAP as foliar spray. However, in other studies BAP as a foliar spray was found to be effective as well in inducing axillary bud sprouting in Macadamia tetraphylla seedlings (Boswell, Nauer, \& Storey, 1981) and to increase lateral shoot production in Abies balsamea trees (Little, 1984, 1985) and to release tillers in oats Avena sativa (Harrison \& Kaufman, 1980).

The theoretical explanation to the clustering of branches can be found in the nutritive theory of hormone action. According to this nutrient hypothesis, nutrient availability in the vicinity of the latent bud is the primary requirement of growth. The mobilization of nutrients to the terminal bud is thought to be created by the presence of a metabolic sink which is a characteristic of high growth centers such as shoot or root apices. Continued growth of the terminal bud thus results in nutrient deprivation of and lack of outgrowth of the lateral buds. The use of BAP and decapitation may have caused the removal of the metabolic sink. This resulted in increased nutrient content in the lateral buds and hence their subsequent out growth. However, according to many reviewers of the subject (Cline, 1997; Cline, 1991; Hillman, 1984; Phillips, 1975; Brown, McAlpine, \& Kormanik, 1967) this nutrient theory has never been unequivocally proved or disproved. The fact that the apical bud is both a nu- 
trient sinks and a source of hormone production has made difficult the testing of both the nutrient and the hormone action hypothesis. Hillman \& Yeang (1981) observed that any treatment that restricts terminal shoot growth would often result in the release of apical dominance. These restrictive treatments would certainly include chemical treatments and decapitation. One of the most straightforward interpretations of these effects is that the acropetal nutrient gradient maintained by the metabolic sink of the growing terminal bud is destroyed by these restrictive treatments and the nutrients then become available for lateral bud outgrowth. Some workers have suggested a secondary role for cytokinin in promoting lateral outgrowth following removal of the auxin source associated with decapitation of the main shoot. Sachs \& Thimann (1967) postulated that cytokinin synthesis in the lateral bud might be induced by the depletion of auxin in the bud while Morris $(1977,1981)$ and Wareing \& Phillips (1981) proposed auxin-ditrcted cytokinin transport from roots to the main shoot apex. Hence, decapitation and the removal of the auxin source will allow diversion of cytokinins to lateral buds and their subsequent outgrowth.

It was not possible to find any information or a similar comparable work in the available literature in which specifically the use of cytokinins caused reversion to the juvenile pinnate leaves in acacias but however, other plant growth hormones were implicated. In this connection, New (1984) stated that pinnate and bipinnate foliage occurs in the juvenile stages of almost all phyllodinous acacias, and more rarely persists in the adult form-which then bears a mosaic of foliage types. According to De Langlade (1965) both pinnate leaves and phyllodes are found on mature shoots of A. melanoxylon. He added that it is possible using treatment with gibberellic acid to cause a reversion of growth form experimentally, so that an adult $A$. melanoxylon will produce juvenile compound leaves. At higher concentrations of gibberellic acid, only juvenile leaves developed on lateral branches, whereas phyllodes developed at low gibberellic acid concentrations (Borchert, 1965; Trippi, 1963). Such reversion can also occur under favourable climatic conditions. One member of the phyllodinae, Acacia latisepala, is particularly unusual in it mixture of foliage, as only a small proportion of plants develop phyllodes and most remain bipinnate throughout their lives (New, 1984). In the light of the foregoing discussion it might be concluded that BAP (cytokinin) can cause similar effect to gibberellic acid on acacias as these group of growth regulators may have some common effects that need further investigation.

Generally all BAP level treatments caused marked reduction in height growth of all the genotypes compared to the control. The decrease in height growth in the present study is in agreement with the findings by Henry \& Fooshee (1985) for Spathiphyllum "Tasson plant" and Little (1985) for Balsam Fir Christmas trees Abies balsamea with cytokinin applications. This decrease in elongation is attributed to the larger lateral shoot number increasing the competition for nutrients and may also to be.due to an inhibitory effect of the surfactant Tween-20 according to Little (1985). On the other hand, basal diameter growth was the least affected variable by the BAP and decapitation treatments though the genotypes showed significant variations between them in this growth characteristic.

The clear bole length is an indication of the self-pruning ability. In forestry, the age at which the lower branches of a tree begin to die and fall off is of much practical importance. In glasshouse-nursery-experiments this characteristic is of less significance as the seedlings are too young. The results indicate that both decapitation and BAP levels significantly decreased the clear bole length of the plants. The genotypes showed significant variation between them with A. mangium provenances producing longer clear bole compared to A. auriculifor$m i s$, which seemed to be naturally low branching provenances. High BAP concentrations induced lower branching especially in $A$. auriculiformis provenances.

The reduction in leaf area as a result to BAP application may be viewed as a transient change for A. auriculiformis. BAP application at the highest concentration used (BAP $1500 \mathrm{mg} \cdot \mathrm{L}^{-1}$ ) generally caused defoliation and eventual mortality in A. mangium provenances but $A$. auriculiformis was less affected. The decrease in total above ground biomass followed the reduction in leaf area and height, but it did not seem to be correlated with the bigger number of branches recorded for the BAP at the higher concentration levels. One explanation for this is that although the branches were numerous but they were mostly small in size and short. Finally it also became evident that $A$. auriculiformis and A. mangium vary in their ability to tolerate relatively higher BAP concentration.

\section{Conclusion}

The application of 6-benzylaminopurine (BAP) as a foliar spray and decapitation did not stimulate multiple 
leader formation in both species. However, both treatments significantly increased the number of branches and produced short blear bole length compared to the control. The use of BAP initiated clustering of branches mostly at the middle of the stem. In addition, BAP treated seedlings developed new juvenile pinnate leaves. In all decapitated seedlings the uppermost shoot grew faster and replaced the decapitated leader shoot and restored the leader dominance.

\section{References}

Bennett, T., \& Leyser, O. (2006). Something on the Side: Axillary Meristems and Plant Development. Plant Molecular Biology, 60, 843-854. http://dx.doi.org/10.1007/s11103-005-2763-4

Borchert, R. (1965). Gibberllic Acid and Rejuvenation of Apical Meristerms in Acacia melanoxylon. Naturwissenschaften, 52, 65-66. http://dx.doi.org/10.1007/BF00695672

Boswell, S. B., \& Storey, W. B. (1974). Cytokinin-Induced Axillary Bud Sprouting in Macadamia. HortScience, 9, $115-116$. http://eurekamag.com/gsearch.php?q=Cytokinin duced+axillary+bud+sprouting+in+macadamia\&cx=003891044927419556404\%3A56otce2mbw0\&cof=FORID\%3A11

Boswell, S. B., Nauer E. M., \& Storey, W. B. (1981). Axillary Buds Sprouting in Macadamia Induced by Two Cytokinins and A Growth Inhibitor. HortScience, 16, 46.

http://eurekamag.com/gsearch.php?q=Axillary+buds+sprouting + in + Macadamia + induced + by + two + cytokinins + and $+a+$ gro wth+inhibitor\&cx=003891044927419556404\%3A56otce2mbw0\&cof=FORID\%3A11

Brar, G. R. P. S. (2012). Effect of Photoperiod, Water Stress and Nitrogen Nutrition on Bud Push, Scion Growth and Cytokinin Content in Container-Grown Citrus Nursery Trees. Ph.D. Thesis, Gainesville: University of Florida. http://ufdc.ufl.edu/UFE0044945/00001

Broome, O. C., \& Zimmerman, R. H. (1976). Breaking Bud Dormancy in Tea Crabapple Malus hupehensis with Cytokinins. Journal of the American Society for Horticultural Sciences, 101, 28-30.

Brown, C. L., McAlpine R. G., \& Kormanik, P. P. (1967). Apical Dominance and Form in Woody Plants: A Reappraisal. American Journal of Botany, 54, 153-162. http://dx.doi.org/10.2307/2440793

http://www.jstor.org/stable/pdfplus/2440793.pdf?acceptTC=true\&acceptTC=true\&jpdConfirm=true

Chen, H. J., Bollmark, M., \& Eliasson, L. (1996). Evidence That Cytokinin Controls Bud Size and Branch Form in Norway Spruce. Physiologia Plantarum, 98, 612-618. http://dx.doi.org/10.1111/j.1399-3054.1996.tb05718.x

Chernyad'ev, (2005). Effect of Water Stress on the Photosynthetic Apparatus of Plants and the Protective Role of Cytokinins: A Review. Applied Biochemistry and Microbiology, 41, 115-128. http://dx.doi.org/10.1007/s10438-005-0021-9

Cline, M. G. (1991). Apical Dominance. The Botanical Review, 57, 318-358. http://dx.doi.org/10.1007/BF02858771

Cline, M. G. (1997). Concepts and Terminology of Apical Dominance. American Journal of Botany, 84, 1064-1069. http://www.amjbot.org/content/84/8/1064.full.pdf http://dx.doi.org/10.2307/2446149

Cohen, M. A. (1978). Shoot Apex Development and Rooting of Pinus strobes L. by Dwarf Shoots. Journal of the American Society for Horticultural Sciences, 103, 483-484.

Croxdale, J. G. (1967). Hormones and Apical Dominance in the Fern Davallia. Journal of Experimental Botany, 27, 801-815. http://dx.doi.org/10.1093/jxb/27.4.801

De Langlade, R. A. (1965). A Comparative Study of The Morphogenesis of Bipinnate Leaves and Phyllodes of Acacia melanoxylon and the Influence of the Environment on the Initiation of Phyllodes. Dissertation Abstracts, $26,647$. http://eurekamag.com/research/024/181/comparative-study-morphogenesis-bipinnate-leaves-phyllodes-acacia-melanoxylo n-effect-environment-initiation-phyllodes.php

Dun E. A., Ferguson B. J., \& Beveridge, C. A. (2006). Apical Dominance and Shoot Branching. Divergent Opinions or Divergent Mechanisms? Plant Physiology, 142, 812-819. http://dx.doi.org/10.1104/pp.106.086868

Eldoma, A. M. A., Kumar, S. M., \& Shukor, N. A. A. (2015) Effects of Site Burning on Multiple Leader Formation and Growth Performance of Selected Acacia Genotypes. American Journal of Plant Sciences, 6, 777-784. http://dx.doi.org/10.4236/ajps.2015.65083

Elfving, D. C. (1984). Factors Affecting Apple-Tree Response to Chemical Branch-Induction Treatments. Journal of the American Society for Horticultural Sciences, 109, 476-481.

http://eurekamag.com/research/001/198/factors-affecting-apple-tree-answer-chemical-branch-induction-treatments.php

Elfving, D. C. (1985). Comparison of Cytokinin and Apical-Dominance-Inhibiting Growth Regulators for Lateral Branch Induction in Nursery and Orchard Apple Trees. HortScience, 60, 447-454.

http://eurekamag.com/research/005/006/comparison-cytokinin-apical-dominance-inhibiting-growth-regulators-lateral-bran ch-induction-nursery-orchard-apple-trees-malus-domestica.php 
Fumey, D., Lauri, P. E., Guedon, Y., Godin, C., \& Costes, E. (2011). How Young Trees Cope with Removal of Whole or Parts of Shoots: An Analysis of Local and Distant Responses to Pruning in 1-Year-Old Apple (Malus $\times$ domestica; Rosaceae) Trees. American Journal of Botany, 98, 1737-1751. http://dx.doi.org/10.3732/ajb.1000231

Harrison, M. A., \& Kaufman, P. B. (1980). Hormonal Regulation of Lateral Bud (Tiller) Release in Oats (Avena sativa L.). Plant Physiology, 66, 1123-1127. http://dx.doi.org/10.1104/pp.66.6.1123

Henny, R. J., \& Fooshee, W. C. (1985). Induction of Basal Shoots in Spathiphyllum "Tasson" Following Treatment with BA. HortScience, 20, 715-717.

Hillman, J. R. (1984). Apical Dominance. In M. B. Wilkins (Ed.), Advanced Plant Physiology (pp. 127-148). London: Pitman.

Hillman, J. R., \& Yeang, H. Y. (1981). Control of Lateral Bud Growth in Phaseolus vulgaris by Ethylene in the Apical Shoot. Journal of Experimental Botany, 30, 395-404.

Ishihara, M. I. (2013). Role of Axis Reversal from the Short-Shoot to Long-Shoot Habit for Crown Maintenance in SlowGrowing Betula maximowicziana Trees. American Journal of Botany, 100, 346-356.

http://dx.doi.org/10.3732/ajb.1200443

Kossuth, S. V. (1978). Induction of Fascicular Buds Development in Pinus sylvesteris L. HortScience, 13, 174-176.

Lauri, P. E. (2007). Differentiation and Growth Traits Associated with Acrotony in the Apple Tree (Malus $\times$ domestica, Rosaceae): American Journal of Botany, 94, 1273-1281. http://dx.doi.org/10.3732/ajb.94.8.1273

Lauri, P. E., Bourdel, G., Trottier, C., \& Cochard, H. (2008). Apple Shoots Architecture: Evidence for Strong Variability of Bud Size and Composition and Hydraulics within a Branching Zone. New Phytologist, 178, 798-807. http://dx.doi.org/10.1111/j.1469-8137.2008.02416.x

Lauri, P. E., Kelner, J. J., Trottier, C., \& Costes, E. (2010). Insights into Secondary Growth in Perennial Plants: Its Unequal Spatial and Temporal Dynamics in the Apple (Malus domestica) Is Driven by Architectural Position and Fruit Load. Annals of Botany, 105, 607-616. http://dx.doi.org/10.1093/aob/mcq006

Leyser, O. (2003). Regulation of Shoot Branching by Auxin. Trends in Plant Science, 8, 541-545. http://dx.doi.org/10.1016/j.tplants.2003.09.008

Little, C. H. A. (1984). Promoting Bud Development in Balsam Fir Christmas Trees with 6-Benzylaminopurine. Canadian Journal of Forest Research, 14, 447-451. http://dx.doi.org/10.1139/x84-079

Little, C. H. A. (1985). Increasing Lateral Shoot Production in Balsam Fir Christmas Trees with Cytokinin Application. HortScience, 25, 64-70. http://cfs.nrcan.gc.ca/publications/?id=7176

Loreti, F., \& Pisani, P. L. (1990). Structural Manipulation for Improved Performance in Woody Plants. HortScience, 25, 64-70.

Monakhova, O. F., \& Chernyad'ev, I. I. (2004). Effects of Cytokinins Preparations on the Stability of the Photosynthetic Apparatus of Two Wheat Cultivars Experiencing Water Deficiency. Applied Biochemistry and Microbiology, 40, 573-580. http://dx.doi.org/10.1023/B:ABIM.0000046993.38857.3e

Morris, D. A. (1977). Transport of Exogenous Auxin in Two-Branched Dwarf Pea Seedlings. Pisum sativum L. Planta, 136, 91-96. http://dx.doi.org/10.1007/BF00387930

Morris, D. A. (1981). Incorporation of Label from Root-Applied N6 (180C) Furfuryladenine into the Guanine Nucleotide Fraction of Pea Bud Ribonucleic Acid. Plant Physiology, 52, 315-319. http://dx.doi.org/10.1111/j.1399-3054.1981.tb08513.x

Nauer, E. M., \& Boswell, S. B. (1981). Stimulating Growth of Quiescent Citrus Buds with 6-Benzylaminopurine. HortScience, 16, 162-163.

New, T. R. (1984). A Biology of Acacias. Melbourne: Oxford University Press.

Ng, F. S. P. (1999). The Development of Tree Trunk in Relation to Apical Dominance and Other Shoot Organization Concepts. Journal of Tropical Forest Science, 11, 270-285.

Philips, I. D. J. (1975). Apical Dominance. Annual Review of Plant Physiology, 26, 341-367. http://dx.doi.org/10.1146/annurev.pp.26.060175.002013

Pospisilova, J., Synkova, H., \& Rulcova, J. (2000). Cytokinins and Water Stress. Biologia Plantarum, 43, 321-328. http://dx.doi.org/10.1023/A:1026754404857

Radhika, \& Thind, S. K. (2013). Biochemical Variation as Influenced by Benzylaminopurine Application in Wheat Genotypes under Variable Water Deficit Conditions. The Institute of Integrative Omics and Applied Biotechnology Journal, 4 , 10-16.

Raza, S. H., Athar, H. R., \& Ashraf, M. (2006). Influence of Exogenously Applied Glycinebetaine on the Photosynthetic Capacity of Two Differently Adapted Wheat Cultivars under Salt Stress. Pakistan Journal of Botany, 38, 341-352.

http://www.pakbs.org/pjbot/PDFs/38(2)/PJB38(2)341.pdf 
Ron'zhina, E. S. (2003). Effect of 6-Benzylaminopurine on The Structure of the Photosynthetic Apparatus of Faba Bean ( $V i$ cia faba L). Applied Biochemistry and Microbiology, 39, 411-417. http://dx.doi.org/10.1023/A:1024580804275

Rubinstein, B., \& Nagao, M. A. (1976). Lateral Bud Outgrowth and Its Control by the Apex. The Botanical Review, 42, 83-113. http://dx.doi.org/10.1007/BF02860863

Sachs, T., \& Thimann, K. V. (1964). Release of Lateral Buds from Apical Dominance. Nature, 201, 939-940. http://dx.doi.org/10.1038/201939a0

Sachs, T., \& Thimann, K. V. (1967). The Role of Auxins and Cytokinin in the Release of Buds from Dominance. American Journal of Botany, 54, 136-144. http://www.jstor.org/stable/2440896 http://dx.doi.org/10.2307/2440896

Trippi, V. S. (1963). Studies on Ontogeny and Senility in Plants. VI. Reversion in Acacia melanoxylon and Morphogentic Changes in Gallardia pulchella. Phyton, International Journal of Experimental Botany, 20, 172-174.

Wareing, P. F., \& Philips, I. D. J. (1981). Growth and Differentiation in Plants. New York: Pergamon Press. http://www.cabdirect.org/abstracts/19710700730.html

Wilson, B. F. (2000). Apical Control of Branch Growth and Angle in Woody Plants. American Journal of Botany, 87, 601607. http://www.amjbot.org/content/87/5/601.full.pdf + html

http://dx.doi.org/10.2307/2656846 